three diatom species we tested ${ }^{1}$ occurred merely in response to alterations in the $\mathrm{CO}_{2}$ concentration, or whether it was also influenced by the concomitant change in $\mathrm{pH}$, cannot be resolved. However, analogous to our experimental design, under natural conditions any change in the $\mathrm{CO}_{2}$ concentration of sea water inevitably goes hand in hand with a change in $\mathrm{pH}$. Thus, a distinction between a $\mathrm{CO}_{2}$ - and a pH-related response in growth rate is not critical for extrapolation of the experimental results to natural conditions. Naturally, we agree that from a physiological point of view this question is of particular interest.

The second point raised by Turpin, the need to distinguish between $\mathrm{CO}_{2}$ limitation of photosynthetic rate and growth rate, is indeed relevant to the interpretation of phytoplankton stable carbon isotope compositions. Because we actually measured growth rate rather than short-term photosynthetic rate, however, our results provide neither a means nor a need to distinguish between the two. In fact, the observed $\mathrm{CO}_{2}$ limitation of growth rate $^{1}$ also implies $\mathrm{CO}_{2}$ limitation of photosynthetic rate.

\section{UIf Rlebesell*}

Dieter Wolf-Gladrow

Vlctor Smetacek

Alfred Wegener Institute for Polar and

Marine Research,

27515 Bremerhaven, Germany

1. RiebeselI, V., Wolf-Gladrow, D. A. \& Smetacek, V Nature 361, 249-251 (1993).

2. Burns, B. D. \& Beardall, J. J. exp. Mar. Biol. Ecol. 107. $75-86$ (1987)

3. Merrett, M. J. Can. J. Bot. 69, 1032-1039 (1991).

4. Rees, T. A. V. J. exp. Bot. 35, 332-337 (1984).

5. Colman, B. \& Rotatore, C. J. exp. Bot. 39, 1025-1032 (1988).

6. Miller, A. G., Turpin, D. H. \& Canvin, D. T. PI. Physiol. 75, 1064-1074 (1984).

7. Turpin, D. H. et al. J. Phycol. 21, 409-418 (1985).

8. Sharkey, T. D. \& Berry, J. A. in Inorganic Carbon Uptake by Aquatic Photosynthetic Organisms (eds Lucas, W. J. \& Berny, J. A.) 389-401 (Am. Soc. PI. Physiol. Rockville, Maryland, 1985).

9. Rau, G. H., Takahashi, T. \& Des Marais, D. J. Nature 341, 516-518 (1989).
3au, G. Hakahashi,

10. Raven, J. A., Johnston, A. M. \& Turpin, D. H. Palaeogeogr. Palaeoclim. Palaeoecol. (in the press).

11. Raven, J. A. PI. Cell Environ. 14, 779-794 (1991)

* Present address: Marine Science Institute, University of California, Santa Barbara, California 93106, USA

\title{
Type 5 adenylyl cyclase distribution
}

SIR - Several groups have reported the identification of eight $\mathrm{G}_{\mathrm{s}}$-sensitive adenylyl cyclases ${ }^{1-11}$ which can be classified into five distinct families. One group reported that an adenylyl cyclase cloned from a striatal complementary DNA library is brain-specific and localized to the striatum $^{11}$. We $\mathrm{W}^{6}$ and others ${ }^{5}$ had cloned the same adenylyl cyclase and called it type 5 . The tissue specificity of the expression of one type of a widespread $\mathrm{G}$

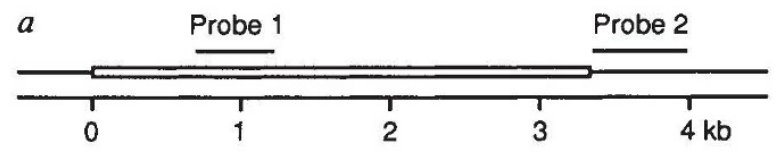

$b$

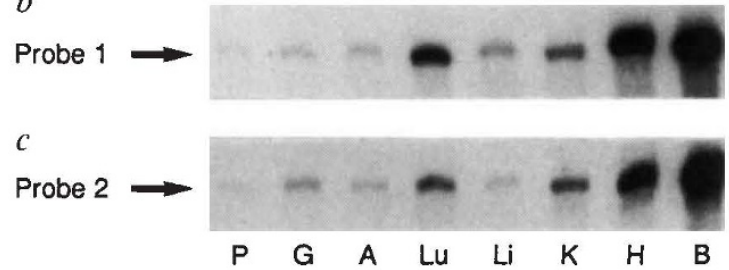

Detection by solution hybridization of mRNA encoding type 5 adenylyl cyclase in various tissues of the rat. $a$, Location of probes along the cDNA for type 5 adenylyl cyclase. $b$, Solution hybridization analysis of total RNA from pancreas $(P)$, gut $(G)$, adrenal gland $(\mathrm{A})$, lung $(\mathrm{Lu})$, liver $(\mathrm{Li})$, kidney $(\mathrm{K})$, heart $(\mathrm{H})$ and brain (B) using probe 1 . Type 5 enzyme mRNA is detected in all tissues. c. Solution hybridization analysis using probe 2. RNA was isolated by the guanidinium thiocyanate method. ${ }^{32} \mathrm{p}$ labelled cRNA probes were prepared, and their sizes were verified by electrophoresis on an acrylamide gel. Samples of total RNA $(10 \mu \mathrm{g})$ from each tissue were analysed for the presence of type 5 adenylyl cyclase mRNA by solution hybridization/RNase protection assay. After digestion, the samples were resolved on an acrylamide gel. Autoradiographs of the gel are shown. ing that Glatt and Snyder ${ }^{11}$ did not detect type 5 mRNA in the heart. Our solution hybridization data are in agreement with those of Ishikawa et al. ${ }^{5}$, which indicate that type 5 adenylyl cyclase mRNA is quite abundant in the heart.

Joseph P. Pleronl

David Miller

RIchard T. Premont

Ravi lyengar

Department of Pharmacology,

Mount Sinai School of Medicine,

One Gustave Levy Place,

New York, New York 10029, USA

1. Krupinski, J. etal. Science 244, 1558-1564 (1989).

2. Bakalyar, H. A. \& Reed, R. R. Science 250, 1403-1406 (1990).

3. Feinstein, P. G. etal. Proc. natn. Acad. Sci. U.S.A. 88 , 10173-10177 (1991).

4. Gao, B. \& Gilman, A. G. Proc. natn. Acad. Sci. U.S.A.88, 10178-10182 (1991).

5. Ishikawa, Y. et al. J. biol. Chem. 267, 13553-13557 (1992).

6. Premont, R. T., Chen, J., Ma, H.-W., Ponnapalli, M. \& lyengar, R. Proc. natn. Acad. Sci. U.S.A. 89, 9809-9813 (1992)

7. Yoshimura, M. \& Cooper, D. M. F. Proc. natn. Acad. Sci. U.S.A. 89, 6716-6720 (1992).

8. Katsushika, S. et al. Proc. natn. Acad. Sci.U.S.A. 89 , 8774-8778(1992)

9. Krupinski, J., Lehman, T. C., Frankenfieid, C. D. Zwaagstra, J. C. \& Watson, P. A. J. biol. Chem. 267, 24858-24862 (1992).

10. Parma, J.etal. Biochem. biophys. Res. Commun. 179 455-462 (1991).

11. Glatt, C. E. \& Snyder, S. H. Nature 361, 536-538 (1993).

12. Premont, R. T. thesis (City Univ. New York, 1992).

GLATT AND SNYDER REPLY - We identified a complementary DNA for an adenylyl cyclase selectively concentrated in the corpus striatum of the brain and thus probably responsible for the synaptic actions of dopamine ${ }^{1}$. The sequence of this DNA is essentially the same as the protein designated adenylyl cyclase type 5 and cloned independently from dog heart ${ }^{2}$ and rat kidney ${ }^{3}$. Although our northern blot analysis did not reveal expression in peripheral tissues or other brain regions, in situ hybridization showed the striatal adenylyl cyclase in the heart and kidney, associated with blood vessels ${ }^{1}$. We have now confirmed these localizations, finding the striatal adenylyl cyclase in the heart concentrated in the atria, aorta and pulmonary artery (unpublished data).

In the pituitary gland we observe the enzyme localized particularly to the anterior lobe. In the kidney, messenger RNA encoding the enzyme is higher in the medulla than the cortex, and associated with tubules. In the eye, the striatal adenylyl cyclase is localized to the retina, both results agreeing with our initial conclusion that the striatal adenylyl cyclase is associated with dopamine's actions ${ }^{1}$. Thus, dopamine neurons and receptors are localized in the retina of the eye $\mathrm{e}^{4}$, in the atria and great vessels of the heart ${ }^{5}$, in the anterior pituitary gland ${ }^{6}$ and in the kidney ${ }^{7}$.

Pieroni et al. have conducted solution hybridization techniques and detect RNA 